\title{
Synergistic Effect of Polysaccharide Gums and Antimicrobial Agents on Susceptibility and Protein Expression of Select Pathogenic Microorganisms in Milk
}

\author{
Bernice Karlton-Senaye ${ }^{1}$, Sarah Adjei-Fremah ${ }^{2}$, Mulumebet Worku ${ }^{2} \&$ Leonard Williams $^{1}$ \\ ${ }^{1}$ Center for Excellence in Post-Harvest Technologies, North Carolina Agricultural and Technical State University, \\ Kannapolis, NC, USA \\ ${ }^{2}$ Department of Animal Science, North Carolina Agricultural and Technical State University, Greensboro, NC, \\ USA \\ Correspondence: Bernice Karlton-Senaye, Center for Excellence in Post-Harvest Technologies, North Carolina \\ Agricultural and Technical State University, Kannapolis, NC 28081, USA. Tel: 1-704-250-5700. E-mail: \\ bekarlton@gmai.com
}

Received: October 17, 2017 Accepted: November 3, $2017 \quad$ Online Published: February 1, 2018

doi:10.5539/jfr.v7n2p35 URL: https://doi.org/10.5539/jfr.v7n2p35

\begin{abstract}
The quest for the use of natural ingredients as preservatives and antimicrobial agents is rising. Polysaccharide gums are usually used as emulsifying agents and as preservatives. The objective of this study was to investigate the combined effect of five different polysaccharide gums and antimicrobial agents on growth, susceptibility and protein expression of select pathogenic microorganisms in milk. Antimicrobial susceptibility and protein concentration were determined by disc diffusion and Pierce BCA assay, respectively. The proteome pattern and the number of protein spots were determined by two-dimensional gel electrophoresis. The results showed that xanthan (6.68 $\pm 0.02 \mathrm{Log} \mathrm{CFU} / \mathrm{mL})$ caused the most growth inhibition of Salmonella enterica, compared to the control. Inclusion of pectin led to a significant $(\mathrm{P}<0.0001)$ 2-log reduction of Salmonella enterica during a 2-day refrigerated storage $\left(4^{\circ} \mathrm{C}\right)$. The highest inhibition zones $(20.50 \pm 0.70)$ was observed in E. coli $\mathrm{O} 157: \mathrm{H} 7$ exposed to carrageenan-maltodextrin-cefixime. The proteome pattern was impacted by the gums with protein band of size $30 \mathrm{kDa}$ being the most prominent band. The highest number of protein spots (35) were obtained in locust bean treated samples. These findings indicated that tested gums affected microbial protein expression and were effective in inhibitory activity against tested pathogens specifically Escherichia coli O157:H7, thus gums hold great promise as some antimicrobial agents. Further characterization of protein targets is warranted.
\end{abstract}

Keywords: polysaccharide gums, antimicrobial, pathogens, and protein expression

\section{Introduction}

There are increasing concerns about issues of food safety and antimicrobial resistance. These concerns come from growing occurrence of new and emerging foodborne disease outbreaks caused by pathogenic microorganisms including Salmonella spp, Escherichia coli, Listeria monocytogenes, Staphylococcus aureus, Bacillus spp. amongst others (Tajkarimi, Ibrahim \& Cliver, 2010). The food industries therefore rely heavily on the use of synthetic preservatives to inactivate or inhibit growth of spoilage and pathogenic microorganisms whereas infected individuals often resort to the use of artificial antimicrobials for recovery from such infections (Demirci, Guven, Demirci, Dadandi and Baser, 2008). Due to the rising incidences of resistance to antimicrobials by microbes natural antimicrobials have gained preference for use as control agents. The benefits of natural antimicrobials include controlling microbial contamination in food, inhibiting pathogenic bacteria, extending shelf life and reducing antibiotic resistance by pathogenic microorganisms (Nazef, Belguesmia, Tani, Pre- vost, \& Drider, 2008; Abou-taleb \& Kawai, 2008).

Antimicrobial resistance remains a critical food safety issue globally as demonstrated by reports on the clinical and public health consequences of drug resistance in E. coli and other foodborne microorganisms. Antimicrobial resistance is acquired through frequent intake of prescription antibiotics because of food contaminations or infections, and antibiotics are often misused in food animals although their primary aim is for disease prevention and growth promotion (Hao et al., 2014). Polysaccharides gums, also referred to hydrocolloids, produced from 
plant, animal, and microbial fermentation have been studied extensively (Jafari et al., 2012). Apart from serving as stabilizers, gums have been used to improve growth and viability in Lactobacillus strains (Hernandez-Hernandez et al., 2012; 2012; Karlton-Senaye, Tahergorabi, Giddings, and Ibrahim, 2014). Certain plant polysaccharide gums have exhibited antimicrobial activity (Yamashita et al., 2001; Ali et al., 2009; Daoud and Roula, 2013). In our previous studies, we demonstrated the combined effect of polysaccharide gums and antimicrobial agents on the growth and antibiotic susceptibility of pathogens in medium (Karlton-Senaye, Ayad, Davis, Khatiwada, and Williams 2016). The physiological response of bacterial cells to antimicrobials is being studied using gene-expression profiling technologies such as proteomic technologies (Pérez-Llarena, and Bou, 2016). Currently, there are few studies performed on the antimicrobial activity but no studies on protein expression of $E$. coli exposed to polysaccharide gums in milk. Therefore, the aim of this study was to investigate the effect of gums on the growth and susceptibility of pathogenic microorganisms and protein expression.

\section{Materials and Methods}

\subsection{Culture Activation}

Stock culture of Escherichia coli O157:H7 (ATCC 700927), Salmonella enterica (ATCC 4345111), Listeria monocytogenes (ATCC19116), and Staphylococcus aureus (ATCC 49775) strains were obtained from $-80^{\circ} \mathrm{C}$ stock storage collections in the microbiology laboratory at the Center for Excellence in Post-Harvest Technologies (Kannapolis, USA). Bacterial cultures were transferred to fresh tryptic soy broth (TSB) then incubation at $37^{\circ} \mathrm{C}$ for $16 \mathrm{~h}$. Activated cultures were streak plated on tryptic soy agar (TSA) and incubated at $37^{\circ} \mathrm{C}$ for $24 \mathrm{~h}$. Single colony of each strain was used for growth study.

\subsection{Treatment Preparation with Different Gums}

Five different gums including agar (AG), carrageenan-maltodextrin (CM), locust bean (LB), pectin (PE), and xanthan (XA) were individually dissolved into $200 \mathrm{~mL}$ batches of $1 \%$ fat liquid milk at $0.5 \%(\mathrm{w} / \mathrm{v})$ and pasteurized at $110^{\circ} \mathrm{C}$ for 10 minutes then cooled to $50^{\circ} \mathrm{C}$ before use (Karlton-Senaye et al., 2014).

\subsection{Inoculation Procedure and Determination of Bacterial Population}

Individual active bacterial culture was serially diluted in $0.1 \%$ peptone water. One milliliter $(\sim 4 \log \mathrm{CFU} / \mathrm{mL})$ from appropriate serial dilution and was inoculated into each $200-\mathrm{mL}$ batch of milk and mixed thoroughly. Initial bacterial populations were determined using a color QCount ${ }^{\circledR}$ Colony Counter (Advanced Instruments Inc., MA, USA). Samples without gum were considered as negative control. Inoculated samples were incubated at $37{ }^{\circ} \mathrm{C}$ for $16 \mathrm{~h}$. After incubation samples were then serially diluted and appropriate diluent was spiral plated onto TSA, and then incubated at $37{ }^{\circ} \mathrm{C}$ for $24 \mathrm{~h}$. The initial and final bacterial population was determined using a color QCount ${ }^{\circledR}$ Colony Counter (Advanced Instruments Inc., MA, USA) (Karlton-Senaye et al., 2016).

\subsection{Storage Study}

After determination of bacterial population samples inoculated with Salmonella enterica were stored at $4{ }^{\circ} \mathrm{C}$ for 21 days. Aliquots from refrigerated samples were serially diluted and spiral plated weekly for 21 days to determine the inhibitory effect of the gum on Salmonella enterica during the refrigerated storage period.

\subsection{Antimicrobial Activity of Bacterial Pre-treated with Gums in Milk}

Antimicrobial activities were detected by the method according to Karlton-Senaye et al., 2016 with a slight modification. Two hundred milliliter $(200 \mathrm{~mL})$ batches of $1 \%$ fat liquid milk (Maola, NC, USA) containing $0.5 \%$ each of the five different gums were inoculated with each of the following pathogenic bacterial strains Escherichia coli O157:H7 (ATCC 700927), Salmonella enterica (ATCC 4345111), Listeria monocytogenes (ATCC 19116), and Staphylococcus aureus (ATCC 49775) and incubated at $37^{\circ} \mathrm{C}$ for $16 \mathrm{~h}$. After incubation milk samples were spirally plated onto Mueller Hinton II Agar (MHA, BBL, Sparks, MD, USA) at a final concentration of $10^{9} \mathrm{cfu} / \mathrm{ml}$. Antibiotic disks (BBL, Sparks, MD, USA) impregnated with the following standard amounts of the active compound were placed in duplicates in appropriate distance on the MHA plates: Tetracycline (TET) $30 \mu \mathrm{g}$; Doripenem (DOR) $10 \mu \mathrm{g}$; Imipenem (IMP) $10 \mu \mathrm{g}$; Cefixime (CFM) $5 \mu \mathrm{g}$; Cipropoxacin (CIP) $5 \mu \mathrm{g}$; Ceftazidime (CAZ) $30 \mu \mathrm{g}$; Kanamycin (KAN) $30 \mu \mathrm{g}$; and Meropenem (MEM) $10 \mu \mathrm{g}$ (BBL, Sparks, MD, USA). The control samples without gums were also treated with antimicrobial agents. Plates were then incubated aerobically at $37^{\circ} \mathrm{C}$ for $24 \mathrm{~h}$. The diameters of inhibition zones were measured and interpreted according to the guidelines provided by the Clinical and Laboratory Standards Institute (2014). The experiments were performed in duplicates and replicated three times. 


\subsection{Protein Profile Studies}

\subsubsection{Endotoxin Assay}

Endotoxin assay was done on all solution and diluents used in this study following the procedure used by Adjei-Fremah et al. (2016). The ToxinSensorTM Chromogenic LAL Endotoxin Assay Kit (GenScript, Piscataway, NJ) was used following the manufacturer's protocol.

\subsubsection{Sample Preparation}

Ten militers $(10 \mathrm{ml})$ of each of treated sample was collected and centrifuged at $3200 \mathrm{~g}$ for 15 minutes. The supernatant was discarded and the cell pellet was resuspended in $5 \mathrm{ml}$ of Phosphate buffered saline (PBS) solution. Protein isolation was done using the B-PER® direct Bacterial Protein Extraction Reagent (Thermo Scientific) following manufacturer's protocol.

\subsubsection{Quantification of Protein Concentration}

The total protein concentration was determined using the Pierce Bicinchoninic assay kit (Thermo-Scientific, Waltham, MA) following manufacturer's protocol. Bovine serum albumin (BSA) with known concentration was used as standard.

\subsubsection{Sodium Dodecyl Sulfate-Polyacrylamide Gel Electrophoresis (SDS-PAGE)}

A volume of the protein sample $(50 \mu \mathrm{g})$ was added to an equal volume of $2 \mathrm{X}$ Laemmli buffer (Bio-rad) and the samples were boiled for $10 \mathrm{~min}$ to denature the proteins. The proteins were then separated on a $4-12 \%$ miniprotean precast gel (Biorad). The SDS-PAGE electrophoresis conditions included $200 \mathrm{~V}, 4000 \mathrm{~mA}$, for 1 hour (Obanla et al., 2016). The proteins were stained using Bio-safe coomassie blue, following manufacturer's procedure (Bio rad). Visualization of proteins was done using Image Lab $^{\mathrm{TM}}$ software version 5.2.1 (Bio-rad). The Precision Plus ${ }^{\mathrm{TM}}$ Protein Dual color (Bio-rad) was used as protein ladder (250kDa-10 kDa).

\subsubsection{Sample Preparation for 2-D Electrophoresis}

The extracted protein samples were further prepped with a ProteoExtract ${ }^{\mathrm{TM}}$ protein precipitation kit (CALBIOCHEM) following the manufacturer's procedure as previously described by Adjei-Fremah et al., (2016). Protein concentration was determined by the Pierce BCA assay using bovine serum albumin as standard.

\subsubsection{D Electrophoresis}

Two-dimension electrophoresis (2-DE) was performed using the ReadyPrep ${ }^{\mathrm{TM}}$ 2-D Starter kit (Bio-Rad) following the manufacturer's manual. Treated and control samples containing $169 \mu \mathrm{g}$ of total proteins were reconstituted with $125 \mathrm{ul}$ of rehydration buffer (10 $\mathrm{ml}$ of $8 \mathrm{M}$ urea, $2 \%$ CHAPS, $50 \mathrm{mM}$ dithiothreitol (DTT), $0.2 \%$ (W/V) Bio-Lyte 3/10 ampholytes and Bromophenol Blue (trace). The reconstituted samples were loaded onto precast IPG ReadyStrips (7cm, pH 3-10, Bio-Rad), and were rehydrated on a level bench for $16 \mathrm{hrs}$. Each of the strips was overlayed with $3 \mathrm{ml}$ of mineral oil to prevent evaporation during the rehydration process. Isoelectric focusing of the proteins was done using a protean isoelectric focusing (IEF) cell (Bio-Rad) at $20^{\circ} \mathrm{C}$ with an initial low voltage $(250 \mathrm{~V}), 4000 \mathrm{~V}$ for $2 \mathrm{hrs}$, followed by a voltage gradient from $10000 \mathrm{Vh}$ to $14,000 \mathrm{Vh}$, with a limiting current of $50 \mu \mathrm{A} /$ strip. Prior to SDS-PAGE, the IEF strips were with equilibration buffer I (6M urea, $2 \%$ SDS, $2 \%$ DTT, $0.375 \mathrm{M}$ Tris-HCl, pH 8.8, 20\% glycerol) and equilibration buffer II (6M urea, 2\% SDS, $2 \%$ DTT, $0.375 \mathrm{M}$ Tris- $\mathrm{HCl}, \mathrm{pH} 8.8,20 \%$ glycerol, $0.5 \mathrm{~g}$ iodoacetamide) for 10 mins each. The equilibrated strips were placed on a gradient polyacrylamide gel (4-15\%), and were sealed with melted agarose gel as an overlay to ensure contact between the strip and gel. SDS-PAGE was carried out using a protean mini apparatus (Bio-Rad) and the electrophoresis was performed at $30 \mathrm{~A}$ for first 1 hour and at $50 \mathrm{~V}, 100 \mathrm{~A} /$ gel until the dye reached the bottom of the gel. The gels were stained with bio-safe Coomassie blue following manufacturer's protocol (Bio-Rad) and further destained in distilled water. After staining, the gels were scanned using a Bio-Rad Image $\mathrm{Lab}^{\mathrm{TM}}$ software version 5.2.1 (Bio-Rad).

\subsubsection{Protein Spot Detection and Quantification}

Protein peak spots analysis was done on the 2D-gel images using the compound fitting algorithm method by Brauner et al. (2014). The compound fitting method uses two dimensional fitting Gaussian function curves to extract data from 2D images. The algorithm used was scripted in MATLAB and is made available as additional file by Brauner et al (2014). The 2DE images were analysed to detect the number of proteins spots, their isoelectric point $(\mathrm{pH})$ and their molecular sizes. Comparative spot analysis was done for presence or absence of protein spot using the $E$. coli $\mathrm{O} 157: \mathrm{H} 7$ Control gel as standard. 


\subsection{Data Analysis}

The mean and standard deviation values were calculated from tested samples from three replicates. The experimental data was analyzed as one-way ANOVA using the GLM procedure of SAS software version 9.4 (SAS, INST., Cary, NC). Statistical significance was considered at $\mathrm{P}<0.0001$. The protein bands were analyzed for percent bands, lane percent, volume (intensity) and relative front using the Image Lab ${ }^{\mathrm{TM}}$ software version 5.2.1 (Bio-rad).

\section{Results}

\subsection{Growth Inhibitory Activities of Gums}

Figure 1 shows effect of gums on the growth of Salmonella enterica (ATCC 4345111), Escherichia coli O157:H7 (ATCC 700927), Staphylococcus aureus (ATTC 49775) and Listeria monocytogenes (ATCC 19116) in $1 \%$ fat fluid milk during $16 \mathrm{~h}$ incubation at $37{ }^{\circ} \mathrm{C}$. The extend of growth inhibition or growth promotion were both strain dependent and on the gums used.

Apart from pectin, all tested gum slightly inhibited the growth of $S$. enterica, with the addition of xanthan $(6.68 \pm 0.02 \mathrm{Log} \mathrm{CFU} / \mathrm{mL}, \mathrm{P}<0.0001)$ causing most growth inhibition compared to the control. The inclusion of pectin led to the least inhibition and most growth of $S$. enterica $(8.09 \pm 0.59 \mathrm{Log}$ CFU $/ \mathrm{mL})$ compared the control (7.56 $\pm 0.13 \mathrm{Log} \mathrm{CFU} / \mathrm{mL})$.

Compare to the control, the inclusion of xanthan, carrageenan-maltodextrin, and pectin led to a slight growth promotion in E. coli $\mathrm{O} 157: \mathrm{H} 7$. In contrast, compared to the control $(7.81 \pm 0.27 \mathrm{Log} \mathrm{CFU} / \mathrm{mL})$, the addition of locust bean and agar led to growth inhibition of Escherichia coli O157:H7 with agar gum (7.56 $\pm 0.41 \mathrm{Log}$ $\mathrm{CFU} / \mathrm{mL})$ causing the least inhibition and carrageenan-maltodextrin the most growth $(8.19 \pm 0.18 \mathrm{Log} \mathrm{CFU} / \mathrm{mL})$.

Compare to the control, the inclusion of locust bean, agar, xanthan, carrageenan-maltodextrin and pectin resulted in a slight growth inhibition of $S$. aureus and L. monocytogenes (Figure 1). The addition of xanthan and carrageenan-maltodextrin led to the most inhibition of $S$. aureus $(8.08 \log \mathrm{CFU} / \mathrm{mL})$ and L. monocytogenes, (7.89 $\log \mathrm{CFU} / \mathrm{mL}$ ) respectively (Figure 1.). 


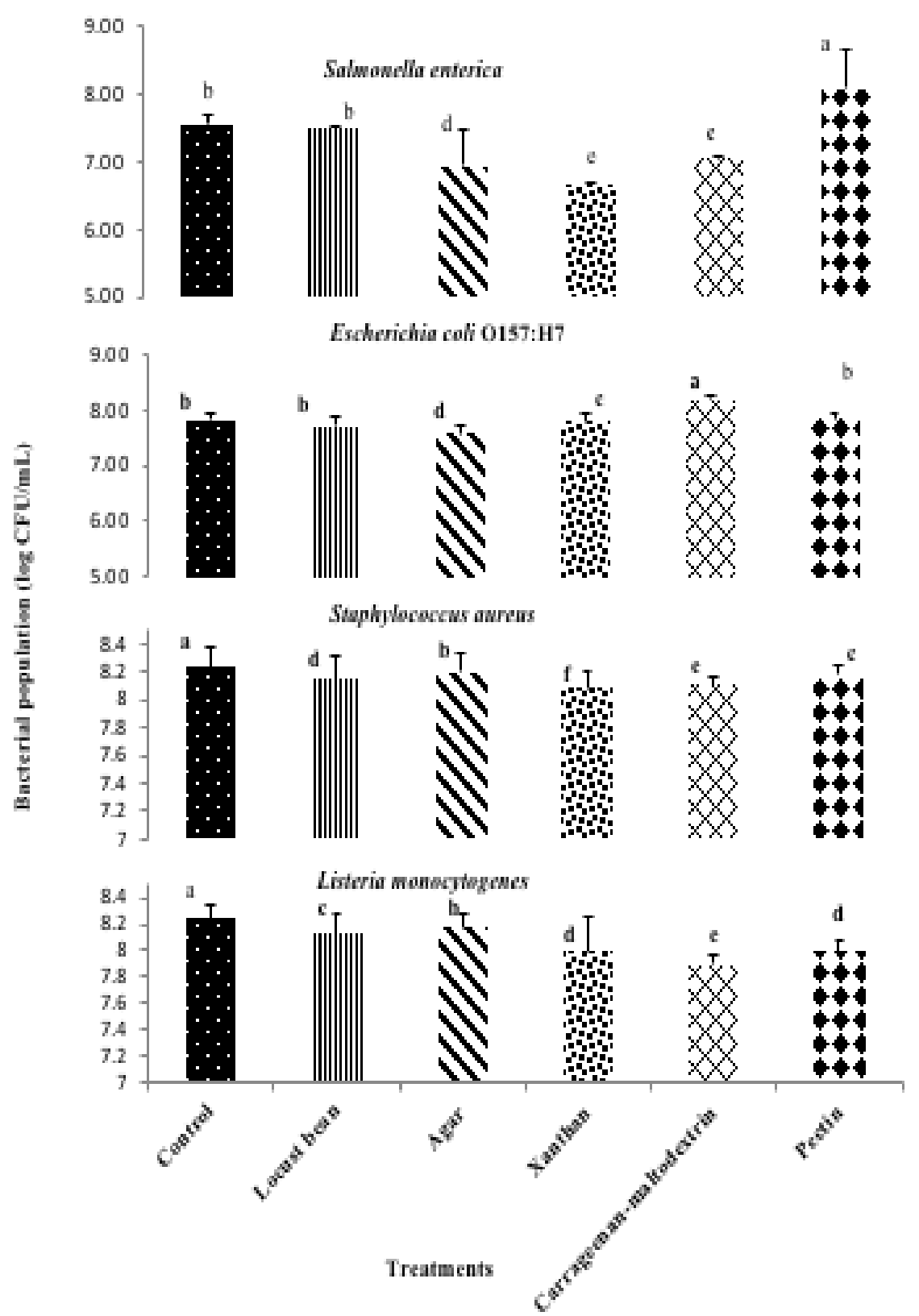

Figure 1. The growth of foodborne pathogens in $1 \%$ liquid milk containing different gums $(0.5 \%)$ incubated at $37^{\circ} \mathrm{C}$ for $16 \mathrm{~h}$. Mean $\pm \mathrm{SD}$ of three independent measurements. Graphs from top to down-Salmonella enterica,

Escherichia coli O157:H7, Staphylococcus aureus and Listeria monocytogenes; Samples: 1-control (milk without gum); 2-treatment (milk +locust bean); 3-treatment (milk +Agar gum); 4-treatment (milk+xanthan);

5-treatment (milk+carrageenan-maltodextrin); 6-treatment (milk+pectin)

\subsection{Effect of Gums on Bacterial Growth During Storage at $4{ }^{\circ} \mathrm{C}$ for 21 Days}

Table 1. shows the combined effect of gums and milk on the growth of $S$. enterica during refrigerated storage at $4{ }^{\circ} \mathrm{C}$. The results showed about a $1-\log$ cfu reduction in both the control and treated samples. However, compared to the control, inclusion of pectin in milk samples led to a 2-log reduction $(\mathrm{P}<0.0001)$ of $S$. enterica on day 21. 
Table 1. Effect of gums on survival of Salmonella enterica during refrigerated storage at $4{ }^{\circ} \mathrm{C}$ for 3 weeks

\begin{tabular}{lc}
\hline Gums & Bacterial population $(\log \mathrm{CFU} / \mathrm{mL})$ \\
\hline Week 1 & $8.04 \pm 0.67^{\mathrm{b}}$ \\
Control & $7.83 \pm 0.86^{\mathrm{d}}$ \\
Locust bean & $7.82 \pm 0.81^{\mathrm{d}}$ \\
Agar & $7.95 \pm 0.85^{\mathrm{c}}$ \\
Xanthan & $7.54 \pm 1.30^{\mathrm{e}}$ \\
Carrageenan-maltodextrin & $8.53 \pm 0.31^{\mathrm{a}}$ \\
Pectin & \\
\hline Week 3 & $7.26 \pm 0.01^{\mathrm{a}}$ \\
\hline Control & $6.83 \pm 0.06^{\mathrm{b}}$ \\
Locust bean & $6.44 \pm 0.04^{\mathrm{e}}$ \\
Agar & $6.65 \pm 0.05^{\mathrm{c}}$ \\
Xanthan & $6.12 \pm 0.04^{\mathrm{f}}$ \\
Carrageenan-maltodextrin & $6.56 \pm 0.16^{\mathrm{d}}$ \\
Pectin &
\end{tabular}

Mean \pm SD of three independent antimicrobial testing.

Means with different letters are significantly different $(\mathrm{P}<0.0001)$

\subsection{Gums and the Antimicrobial Susceptibility of Pathogens}

The synergistic effect of gums and milk on antimicrobial susceptibility of the tested foodborne pathogens was presented in Tables 2-6. With a few exceptions, the results showed, polysaccharide gums increased the susceptibility of tested pathogens to all antimicrobial agents compared to the control. The addition of all tested gums in milk rendered S. enterica susceptible to TET and DOR, although the control sample remained resistant. Inclusion of xanthan $(46.5 \pm 0.57 \mathrm{~mm})$ and carrageenan-maltodextrin $(46.25 \pm 0.57 \mathrm{~mm})$ increased the susceptibility of Salmonella enterica by more than two-fold (Table 2.). However, S. enterica remained resistant to CFM in both the control and the treatments. Notably, treatment of $S$. enterica with pectin resulted in resistance of $S$. enterica to CIP, CAZ, KAN and CFM.

Table 2. Combine effect of gums on antimicrobial agents on susceptibility of Salmonella enterica (ATCC 4345111) incubated at $37^{\circ} \mathrm{C}$ for $16 \mathrm{~h}$

\begin{tabular}{lllll}
\hline Gums/Antimicrobial agents & \multicolumn{4}{l}{ Zone of inhibition $(\mathrm{mm})$} \\
\hline Control & TET & DOR & IMP & CFM \\
Locust bean & $-(\mathrm{R})$ & $-(\mathrm{R})$ & $20.00 \pm 0.81(\mathrm{~S})$ & $-(\mathrm{R})$ \\
Agar & $28.25 \pm 0.5(\mathrm{~S})$ & $30.25 \pm 0.5(\mathrm{~S})$ & $29.25 \pm 0.95(\mathrm{~S})$ & $-(\mathrm{R})$ \\
Xanthan & $26.75 \pm 0.9(\mathrm{~S})$ & $23.25 \pm 0.5(\mathrm{~S})$ & $43.50 \pm 0.57(\mathrm{~S})$ & $-(\mathrm{R})$ \\
Carrageenan-maltodextrin & $26.5 \pm 0.9(\mathrm{~S})$ & $25.25 \pm 0.5(\mathrm{~S})$ & $46.50 \pm 0.57(\mathrm{~S})$ & $-(\mathrm{R})$ \\
Pectin & $38.00 \pm 0.81(\mathrm{~S})$ & $37.25 \pm 0.5(\mathrm{~S})$ & $46.25 \pm 0.50(\mathrm{~S})$ & $-(\mathrm{R})$ \\
& $23.75 \pm 0.5(\mathrm{~S})$ & $14.50 \pm 0.57(\mathrm{~S})$ & $22.50 \pm 0.57(\mathrm{~S})$ & $-(\mathrm{R})$ \\
Control & $\mathrm{CIP}$ & $\mathrm{CAZ}$ & $\mathrm{KAN}$ & $\mathrm{MEM}$ \\
Locust bean & $-(\mathrm{R})$ & $-(\mathrm{R})$ & $-(\mathrm{R})$ & $-(\mathrm{R})$ \\
Agar & $-(\mathrm{R})$ & $-(\mathrm{R})$ & $-(\mathrm{R})$ & $12.50 \pm 0.57(\mathrm{~S})$ \\
Xanthan & $32.00 \pm 2.31(\mathrm{~S})$ & $-(\mathrm{R})$ & $24.75 \pm 1.26(\mathrm{~S})$ & $13.50 \pm 0.57(\mathrm{~S})$ \\
Carrageenan-maltodextrin & $32.75 \pm 2.06(\mathrm{~S})$ & $14.75 \pm 0.5(\mathrm{~S})$ & $27.25 \pm 0.5(\mathrm{~S})$ & $15.50 \pm 0.57(\mathrm{~S})$ \\
Pectin & $32.50 \pm 0.57(\mathrm{~S})$ & $-(\mathrm{R})$ & $26.50 \pm 0.58(\mathrm{~S})$ & $14.75 \pm 0.50(\mathrm{~S})$ \\
\hline
\end{tabular}

Tetracycline (TET-30 $\mu \mathrm{g}$ ); Doripenem (DOR-10 $\mu \mathrm{g}$ ); Imipenem (IMP-10 $\mu \mathrm{g}$ ); Cefixime (CFM-5 $\mu \mathrm{g}$ ); Cipropoxacin (CIP-5 $\mu \mathrm{g}$ ); Ceftazidime (CAZ-30 $\mu \mathrm{g}$ ); Kanamycin (KAN-30 $\mu \mathrm{g}$ ); and Meropenem (MEM-10 $\mu \mathrm{g}$ ). Mean of three independent antimicrobial testing. Zone of inhibition was measured in nearest millimeter (mm) and interpreted based on NCLS for breakpoints. S: Susceptible; R: Resistance; (-): no zone of inhibition. 


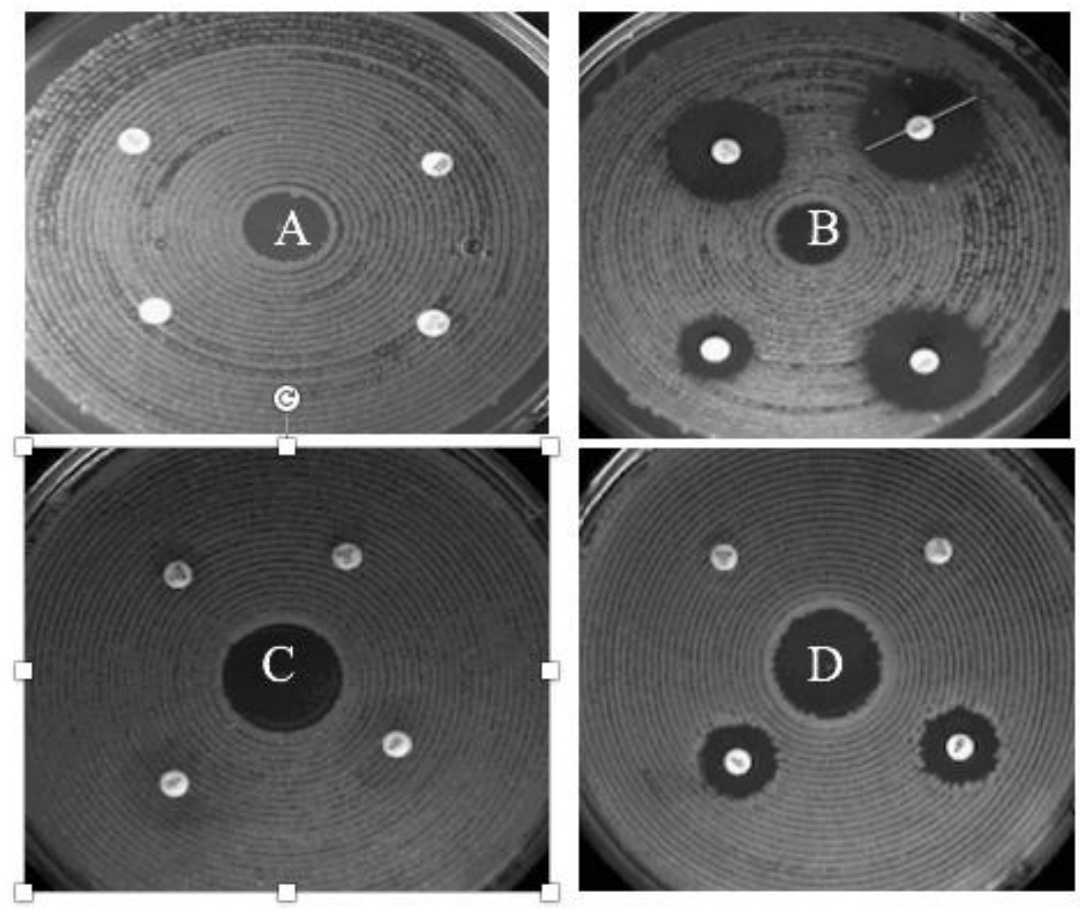

Figure 2. Comparing the effect of gums on antimicrobial susceptibility of Salmonella enterica in $1 \%$ liquid milk. Pre-treatment of Salmonella enterica with locust bean (top 2) and xanthan (bottom 2) followed by exposure to DOR and KAN resulted in making Salmonella enterica susceptible

Similar trends were observed in Table 3. that showed the effect of gums on susceptibility of E. coli O157:H7. Except for locust bean, the presence of all polysaccharide gums improved the susceptibility of E. coli O157:H7 to Ceftazidime (CFM) with up to $20.5 \pm 0.70 \mathrm{~mm}$ inhibition zone. However, pretreatment with locust bean either decreased or maintained the susceptibility of E. coli $\mathrm{O} 157: \mathrm{H} 7$ to all tested antimicrobial agents. The zone of inhibition increased by $9.5 \mathrm{~mm}, 9 \mathrm{~mm}, 8.5 \mathrm{~mm}$ in agar-Tetracycline, agar-doripenem, and agar-impinem, respectively, compared to their control.

Table 3. Combine effect of gums and antimicrobials on susceptibility of Escherichia coli O157:H7 (ATCC 700927) incubated at $37^{\circ} \mathrm{C}$ for $16 \mathrm{~h}$

\begin{tabular}{lllll}
\hline Gums/Antimicrobial agents & \multicolumn{4}{c}{ Zone of inhibition (mm) } \\
\hline Control & TET & DOR & IMP & CFM \\
Locust bean & $27.50 \pm 0.71(\mathrm{~S})$ & $37.50 \pm 2.12(\mathrm{~S})$ & $42.00 \pm 2.8(\mathrm{~S})$ & $-(\mathrm{R})$ \\
Agar & $24.00 \pm 1.41(\mathrm{~S})$ & $34.00 \pm 1.41(\mathrm{~S})$ & $39.50 \pm 0.71(\mathrm{~S})$ & $-(\mathrm{R})$ \\
Xanthan & $36.50 \pm 0.71(\mathrm{~S})$ & $46.50 \pm 0.71(\mathrm{~S})$ & $50.50 \pm 2.12(\mathrm{~S})$ & $16.50 \pm 0.71(\mathrm{~S})$ \\
Carrageenan-maltodextrin & $33.50 \pm 0.71(\mathrm{~S})$ & $42.50 \pm 0.71(\mathrm{~S})$ & $48.50 \pm 0.71(\mathrm{~S})$ & $16.50 \pm 0.71(\mathrm{~S})$ \\
Pectin & $23.50 \pm 2.12(\mathrm{~S})$ & $45.50 \pm 0.70(\mathrm{~S})$ & $47.00 \pm 2.83(\mathrm{~S})$ & $20.50 \pm 0.70(\mathrm{~S})$ \\
& $24.50 \pm 3.53(\mathrm{~S})$ & $41.50 \pm 2.12(\mathrm{~S})$ & $45.00 \pm 1.41(\mathrm{~S})$ & $12.50 \pm 0.70(\mathrm{~S})$ \\
\hline Control & CIP & CAZ & KAN & MEM \\
Locust bean & $32.50 \pm 0.71(\mathrm{~S})$ & $24.00 \pm 1.41(\mathrm{~S})$ & $25.50 \pm 0.70(\mathrm{~S})$ & $38.00 \pm 2.83(\mathrm{~S})$ \\
Agar & $32.50 \pm 0.70(\mathrm{~S})$ & $24.00 \pm 1.41(\mathrm{~S})$ & $24.50 \pm 0.71(\mathrm{~S})$ & $32.00 \pm 1.41(\mathrm{~S})$ \\
Xanthan & $34.50 \pm 0.71(\mathrm{~S})$ & $25.00 \pm 2.82(\mathrm{~S})$ & $32.00 \pm 1.41(\mathrm{~S})$ & $43.00 \pm 1.41(\mathrm{~S})$ \\
Carrageenan-maltodextrin & $33.00 \pm 1.41(\mathrm{~S})$ & $24.50 \pm 0.71(\mathrm{~S})$ & $28.50 \pm 0.71(\mathrm{~S})$ & $40.50 \pm 0.71(\mathrm{~S})$ \\
Pectin & $39.50 \pm 0.71(\mathrm{~S})$ & $28.50 \pm 2.12(\mathrm{~S})$ & $36.00 \pm 1.41(\mathrm{~S})$ & $40.50 \pm 0.71(\mathrm{~S})$ \\
& $33.50 \pm 2.12(\mathrm{~S})$ & $24.50 \pm 0.70(\mathrm{~S})$ & $30.50 \pm 0.70(\mathrm{~S})$ & $39.50 \pm 0.70(\mathrm{~S})$ \\
\hline
\end{tabular}

Tetracycline (TET-30 $\mu \mathrm{g})$; Doripenem (DOR-10 $\mu \mathrm{g})$; Imipenem (IMP-10 $\mu \mathrm{g}$ ); Cefixime (CFM-5 $\mu \mathrm{g})$; Cipropoxacin (CIP-5 $\mu \mathrm{g})$; Ceftazidime (CAZ-30 $\mu \mathrm{g})$; Kanamycin (KAN-30 $\mu \mathrm{g})$; and Meropenem (MEM-10 $\mu \mathrm{g})$. Mean of three independent antimicrobial testing. Zone of inhibition was measured in nearest millimeter (mm) and interpreted based on NCLS for breakpoints. S: Susceptible; R: Resistance; (-): no zone of inhibition. 
Contrastingly, tested gums showed very little or no effect on the susceptibility of $S$. aureus (Table 4). Whereas $S$. aureus showed resistance to TET, CFM, CAZ and KAN even with treatment with gums, a minimal or no effect on susceptibility to DOR, IMP, CIP and MEM was observed in treatments (Table 4.).

Table 4. Combine effect of gums and antimicrobials on susceptibility of Staphylococcus aureus (ATCC 49775) incubated at $37^{\circ} \mathrm{C}$ for $16 \mathrm{~h}$

\begin{tabular}{|c|c|c|c|c|}
\hline \multirow{2}{*}{ Gums/Antimicrobial gents } & \multicolumn{4}{|c|}{ Zone of inhibition (mm) } \\
\hline & TET & DOR & IMP & CFM \\
\hline Control & $-(\mathrm{R})$ & $17.50 \pm 0.70(\mathrm{~S})$ & $18.75 \pm 0.35(\mathrm{~S})$ & $-(\mathrm{R})$ \\
\hline Locust bean & $-(\mathrm{R})$ & $22.50 \pm 0.70(\mathrm{~S})$ & $19.25 \pm 1.06(\mathrm{~S})$ & $-(\mathrm{R})$ \\
\hline Agar & $-(\mathrm{R})$ & $21.50 \pm 2.12(\mathrm{~S})$ & $21.50 \pm 0.71(\mathrm{~S})$ & $-(\mathrm{R})$ \\
\hline Xanthan & $-(\mathrm{R})$ & $19.50 \pm 0.70(\mathrm{~S})$ & $23.00 \pm 1.41(\mathrm{~S})$ & $-(\mathrm{R})$ \\
\hline Carrageenan-maltodextrin & $-(\mathrm{R})$ & $19.00 \pm 1.41(\mathrm{~S})$ & $21.50 \pm 0.71(\mathrm{~S})$ & $-(\mathrm{R})$ \\
\hline \multirow[t]{2}{*}{ Pectin } & $-(\mathrm{R})$ & $21.00 \pm 1.41(\mathrm{~S})$ & $23.00 \pm 1.41(\mathrm{~S})$ & $-(\mathrm{R})$ \\
\hline & CIP & CAZ & KAN & MEM \\
\hline Control & $11.00 \pm 1.41(\mathrm{~S})$ & $-(\mathrm{R})$ & - (R) & $15.50 \pm 0.70(\mathrm{~S})$ \\
\hline Locust bean & $11.00 \pm 1.41(\mathrm{~S})$ & $-(\mathrm{R})$ & $-(\mathrm{R})$ & $17.50 \pm 0.71(\mathrm{~S})$ \\
\hline Agar & $11.00 \pm 1.41(\mathrm{~S})$ & $-(\mathrm{R})$ & $-(\mathrm{R})$ & $16.50 \pm 0.71(\mathrm{~S})$ \\
\hline Xanthan & $18.50 \pm 0.71(\mathrm{~S})$ & $-(\mathrm{R})$ & - (R) & $18.00 \pm 1.41(\mathrm{~S})$ \\
\hline Carrageenan-maltodextrin & $17.75 \pm 0.35(\mathrm{~S})$ & $-(\mathrm{R})$ & - (R) & $17.50 \pm 0.71(\mathrm{~S})$ \\
\hline Pectin & $11.00 \pm 1.41(\mathrm{~S})$ & $-(\mathrm{R})$ & $-(\mathrm{R})$ & $15.50 \pm 0.71(\mathrm{~S})$ \\
\hline
\end{tabular}

Tetracycline (TET-30 $\mu \mathrm{g}$ ); Doripenem (DOR-10 $\mu \mathrm{g}$ ); Imipenem (IMP-10 $\mu \mathrm{g}$ ); Cefixime (CFM-5 $\mu \mathrm{g}$ ); Cipropoxacin (CIP-5 $\mu \mathrm{g}$ ); Ceftazidime (CAZ-30 $\mu \mathrm{g}$ ); Kanamycin (KAN-30 $\mu \mathrm{g})$; and Meropenem (MEM-10 $\mu \mathrm{g})$. Mean of three independent antimicrobial testing. Zone of inhibition was measured in nearest millimeter (mm) and interpreted based on NCLS for breakpoints. S: Susceptible; R: Resistance; (-): no zone of inhibition.

Similarly, Listeria monocytogenes was resistant against TET, CFM, CAZ and KAN in both the treatments and the control. However, a minimal inhibitory activity to DOR, IMP, CIP and MEM was observed in treated samples. Interestingly, pre-treatment of $L$. monocytogenes with either locust bean or agar in milk resulted little or no different in zone size compared to the control $(18.25 \pm 0.35 \mathrm{~mm})$. The highest zone size $(23.5 \pm 0.71 \mathrm{~mm})$ was exhibited in samples that were pretreated with xanthan and exposed to IMP (Table 5).

Table 5. Combine effect of gums and antimicrobials on susceptibility of Listeria monocytogenes (ATCC 19116) incubated at $37^{\circ} \mathrm{C}$ for $16 \mathrm{~h}$

\begin{tabular}{lllll}
\hline Gums/Antimicrobial gents & \multicolumn{4}{c}{ Zone of inhibition (mm) } \\
\hline Control & TET & DOR & IMP & CFM \\
Locust bean & $-(\mathrm{R})$ & $18.25 \pm 0.35(\mathrm{~S})$ & $18.25 \pm 0.35(\mathrm{~S})$ & $-(\mathrm{R})$ \\
Agar & $-(\mathrm{R})$ & $18.25 \pm 0.35(\mathrm{~S})$ & $18.25 \pm 0.35(\mathrm{~S})$ & $-(\mathrm{R})$ \\
Xanthan & $-(\mathrm{R})$ & $18.25 \pm 0.35(\mathrm{~S})$ & $18.25 \pm 0.35(\mathrm{~S})$ & $-(\mathrm{R})$ \\
Carrageenan-maltodextrin & $-(\mathrm{R})$ & $18.25 \pm 0.35(\mathrm{~S})$ & $23.5 \pm 0.71(\mathrm{~S})$ & $-(\mathrm{R})$ \\
Pectin & $-(\mathrm{R})$ & $19.50 \pm 0.70(\mathrm{~S})$ & $22.5 \pm 0.71(\mathrm{~S})$ & $-(\mathrm{R})$ \\
& $-(\mathrm{R})$ & $21.00 \pm 1.41(\mathrm{~S})$ & $21.00 \pm 0.70(\mathrm{~S})$ & $-(\mathrm{R})$ \\
\hline Control & $\mathrm{CIP}$ & $\mathrm{CAZ}$ & $\mathrm{KAN}$ & MEM \\
Locust bean & $11.15 \pm 0.21(\mathrm{~S})$ & $-(\mathrm{R})$ & $-(\mathrm{R})$ & $17.65 \pm 0.49(\mathrm{~S})$ \\
Agar & $12.15 \pm 0.21(\mathrm{~S})$ & $-(\mathrm{R})$ & $-(\mathrm{R})$ & $19.35 \pm 0.47(\mathrm{~S})$ \\
Xanthan & $12.75 \pm 0.35(\mathrm{~S})$ & $-(\mathrm{R})$ & $-(\mathrm{R})$ & $17.50 \pm 0.70(\mathrm{~S})$ \\
Carrageenan-maltodextrin & $11.50 \pm 0.71(\mathrm{~S})$ & $-(\mathrm{R})$ & $-(\mathrm{R})$ & $17.67 \pm 0.70(\mathrm{~S})$ \\
Pectin & $12.50 \pm 0.71(\mathrm{~S})$ & $-(\mathrm{R})$ & $-(\mathrm{R})$ & $21.50 \pm 0.94(\mathrm{~S})$ \\
\hline
\end{tabular}

Tetracycline (TET-30 $\mu \mathrm{g}$ ); Doripenem (DOR-10 $\mu \mathrm{g}$ ); Imipenem (IMP-10 $\mu \mathrm{g}$ ); Cefixime (CFM-5 $\mu \mathrm{g}$ ); Cipropoxacin (CIP-5 $\mu \mathrm{g}$ ); Ceftazidime (CAZ-30 $\mu \mathrm{g}$ ); Kanamycin (KAN-30 $\mu \mathrm{g})$; and Meropenem (MEM-10 $\mu \mathrm{g})$. Mean of three independent antimicrobial testing. Zone of inhibition was measured in nearest millimeter (mm) and interpreted based on NCLS for breakpoints. S: Susceptible; R: Resistance; (-): no zone of inhibition. 


\subsection{Effect of Polysaccharide Gums on Protein Expression}

\subsubsection{Total Protein Concentration}

The effect of the gums on protein expression in Salmonella enterica was summarized in Figure 3. Total protein expressed has increased in all treatment in comparison to the control. Treatment with agar gum $(110,000 \mu \mathrm{g} / \mathrm{ml})$ resulted in the highest concentration of protein expression whereas treatment with xanthan $(5000 \mu \mathrm{g} / \mathrm{ml})$ depicted the lowest total protein concentration compared to the other treatments. Expression profiles monitored by gel electrophoresis (SDS-PAGE) showed some variation between treatments, control and the blank (milk only). There were 10 bands in blank, 8 bands in the control and 7 bands in sample treated with locust bean. On the other hand, 6 protein bands were seen in the expression profile for samples containing agar, xanthan, carrageenan-maltodextrin and pectin. About 7 to 12 protein bands of size $250-10 \mathrm{kDa}$ were detected among all treatment groups with variable band volume intensity. Protein band of size $30 \mathrm{kDa}$ was the most prominent band among all treatments. However, the band intensity of this prominent protein decreased in treatment with xanthan, and highest band intensity in samples treated with locust bean and pectin, compared to the others. A protein band of size $12.5 \mathrm{kDA}$ was present in control and in samples treated with locust bean, agar gum and xanthan, but was absent in carrageenan and pectin treated samples.
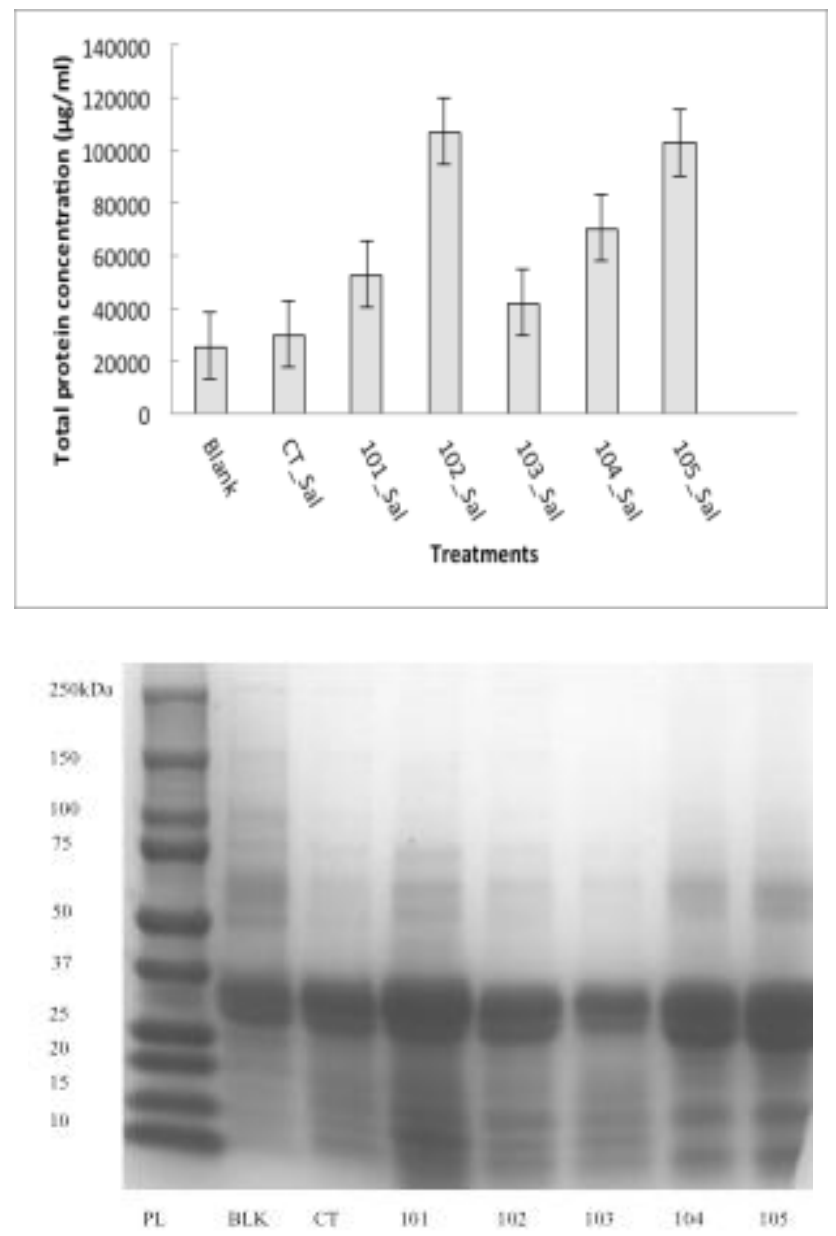

Figure 3. Effect of gums on total protein expression of Salmonella enterica in milk. CT: control; 101: locust bean; 102: agar gum; 103: xanthan; 104: carrageenan-maltodextrin; 105: pectin. BLK: 12 bands; CT: 11; 101: 9; 102: 10; 103: 7; 104: 8; 105: 8

Figure 4. shows effect of gums on total protein expression and gel intensity of Escherichia coli O157:H7 in milk, respectively. All treatments except locust bean treated sample had decreased total protein concentration compared to the control. Treatment with pectin resulted in the least protein levels. Four protein bands were common between blank, control, and all the treated samples at $65 \mathrm{kDA}, 37 \mathrm{kDA}, 18 \mathrm{kDA}$ and $12 \mathrm{kDA}$. The protein 
bands of size 30kDA were of strongest intensity in control, locust bean and agar treated samples, however lower band intensity band was observed in sample treated with xanthan and carrageenan-maltodextrin treated samples. A $20 \mathrm{kDA}$ protein band was distinctively present in samples treated with xanthan and carrageenan-maltodextrin. It was also observed that, a protein of size $60 \mathrm{kDA}$ was absent in samples treated with xanthan and carrageenan-maltodextrin.
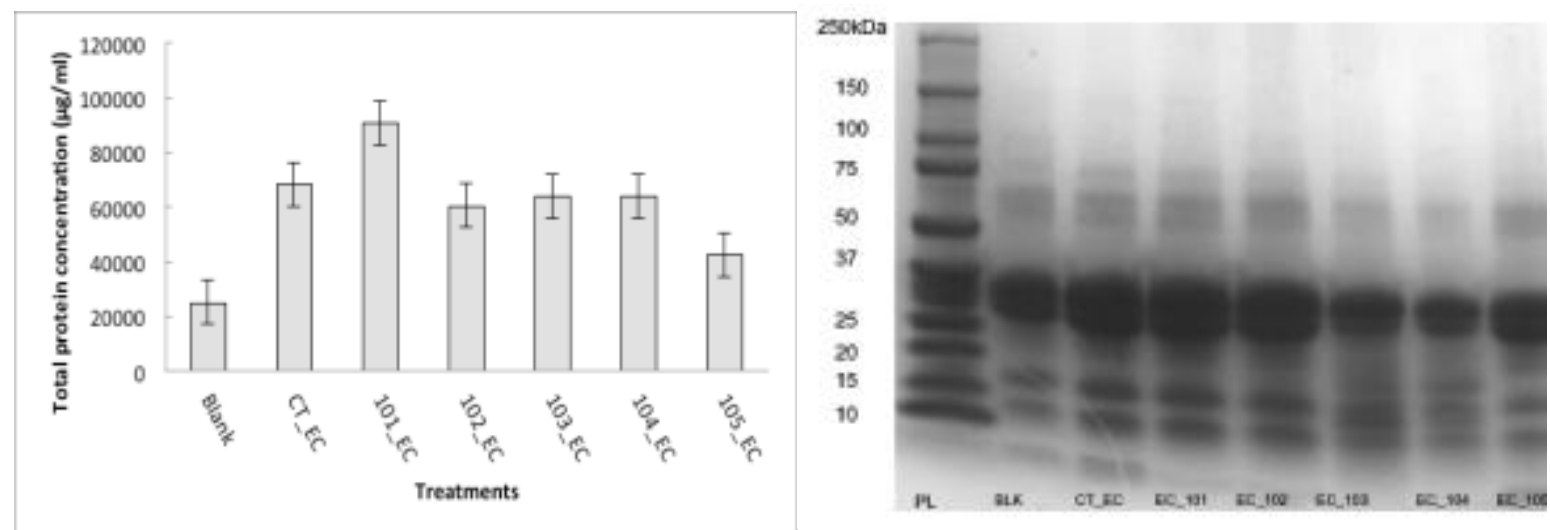

Figure 4. Effect of gums on total protein expression of Escherichia coli in milk. CT: (E. coli only); 101: (E. coli and locust bean); 102: (E. coli and agar gum; 103: (E. coli and xanthan); 104: (E. coli and

carrageenan-maltodextrin); 105: (E. coli and pectin). SDS page result (right): BLK: Blank (milk only): 10 bands; CT-EC: 8 bands; EC_101: 7 bands; EC_102: 6; EC_103: 6; EC_104: 6 and EC_105: 6 bands

Protein expression in Staphylococcus aureus is summarized in Figure 5. The results showed that with the exception locust bean, all treatments inhibited the activity of Staphylococcus aureus and hence the reduced total protein concentration observed. Six protein bands of size 150-10kDa were detected among all treatment groups with variable band volume intensity. Protein band of size $30 \mathrm{kDa}$ was the most prominent band among all treatments, however, the band intensity of this protein decreased in treatment containing locust bean and carrageenan, and highest band intensity in agar and pectin treated samples, compared to control. Protein band of sizes $15 \mathrm{kDA}$ and $100 \mathrm{kDA}$ were present in treatments except samples with carrageenan-maltodextrin.
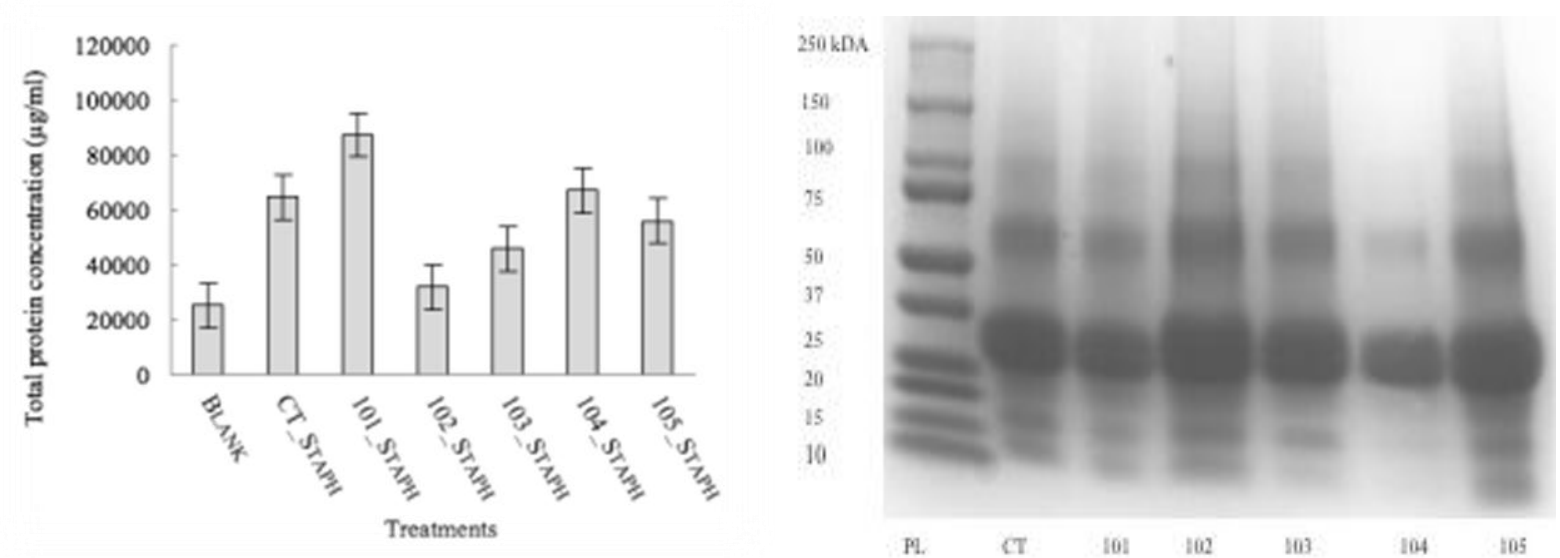

Figure 5. Effect of gums on total protein expression of Staphylococcus aureus in milk. PL: Protein ladder (250 kDa); Blank (without gum and S. aureus) CT: control (S. aureus only); 101: (S. aureus and locust bean); 102: (S. aureus and agar gum); 103: (S. aureus and xanthan); 104: (S. aureus and carrageenan-maltodextrin); 105: (S. aureus and pectin)

Figure 6. shows the effect of gums on protein expression in Listeria monocytogenes. Compared to the control, treatment with all the different gums increased total protein concentration. Treatment with pectin led to the highest total expression. It was also observed that the total protein expressed in both blank and control showed no difference. Six protein bands of size $150-10 \mathrm{kDa}$ were detected among all treatment groups with variable band volume intensity. Protein band of size $30 \mathrm{kDa}$ was the most prominent band among all treatments. However, 
the band intensity of this protein was found to be highest in control compared all the samples treated with gum.
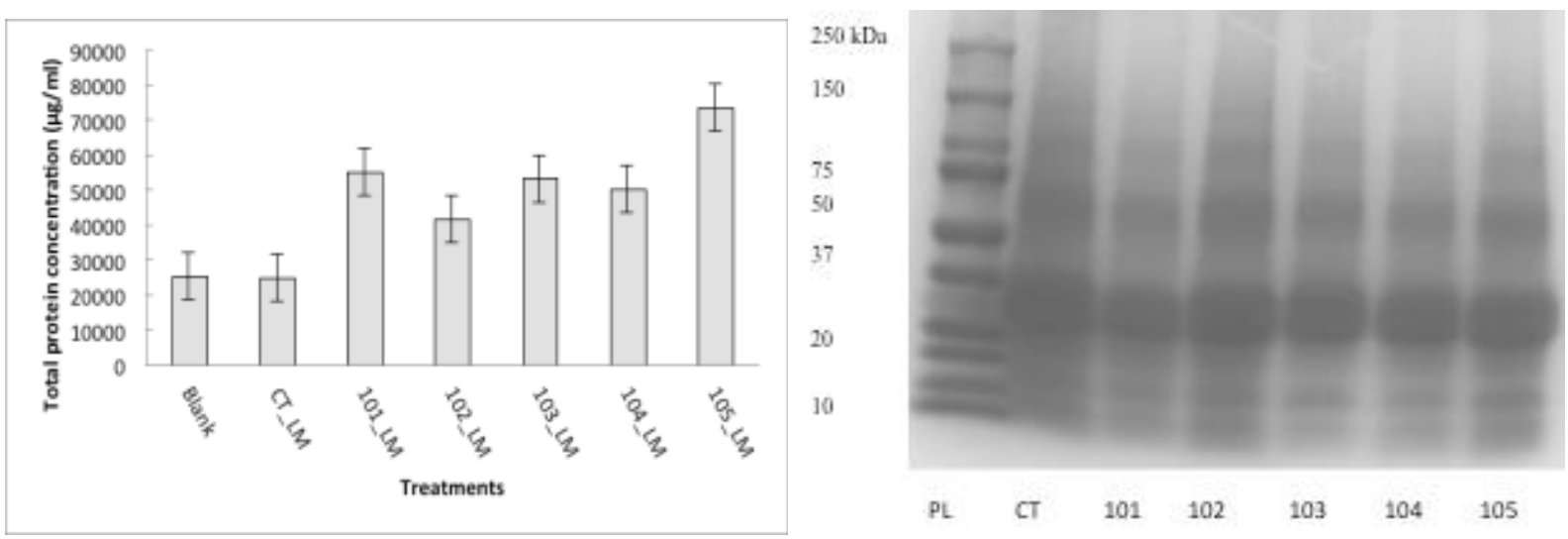

Figure 6. Effect of gums on total protein expression of Listeria monocytogenes in milk. PL: Protein ladder (250 $\mathrm{kDa}$ ); Blank (without gum and L. monocytogenes) CT: (L. monocytogenes only) 101: (L. monocytogenes and locust bean); 102: (L. monocytogenes and agar gum); 103: (L. monocytogenes and xanthan); 104: ( $L$. monocytogenes and carrageenan-maltodextrin); 105: (L. monocytogenes and pectin)

further studies were carried out to determine the effect of the tested gums on the number of protein spots expressed in E. coli O157:H7 using 2DE. Figures 7 and 8 depict a standard 2-DE gel image of E. coli proteome using $\mathrm{pH} 3-10$, and 4-7 IPG strips. The 2DE gel images showing the effect of different gum treatments on E. coli is shown in Figure 9 to 14. Variations in entire proteome profile of E. coli O157:H7 in response to gums treatment were observed by comparing the 2-DE image of control to treated groups. Compound fitting algorithm (Brauner et al., 2014) analysis of the 2DE gels (Figures15) were performed to determine the number of protein spots in each treatment group. About twenty-three protein peak spots were identified in the control sample (Figure 9) usually within the $\mathrm{pH}$ ranges 4-6 and 8-10 (Table 6).

Highest number of protein spots (35) with greater intensity were obtained in the samples treated with locust bean (Figure 10) compared to the other treatment groups and the control. Additionally, about four protein spots at the isoelectric point $\mathrm{pH} 3$ and molecular size ranging 10-50 kDa were distinctively present in locust bean treated groups but absent in the control (Figure 10). Also, a few protein spots with less intensity were detected in xanthan and carrageenan-maltodextrin treatment groups. The detected protein spots in the $\mathrm{pH}$ range of 8-10 had a horizontal train aspect, and this is typical of glycosylated/ phosphorylated proteins.

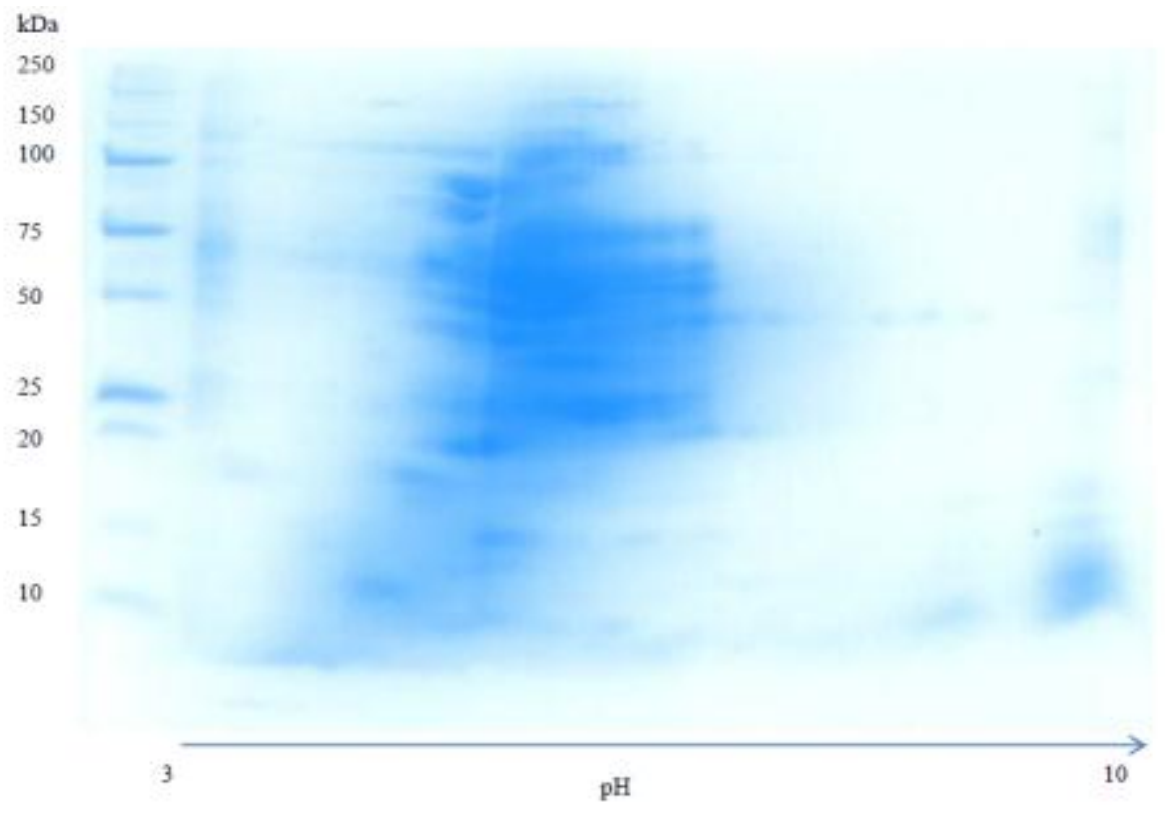

Figure 7. Expression of protein in E. coli $\mathrm{O} 157: \mathrm{H} 7$ at 3-10 pH 


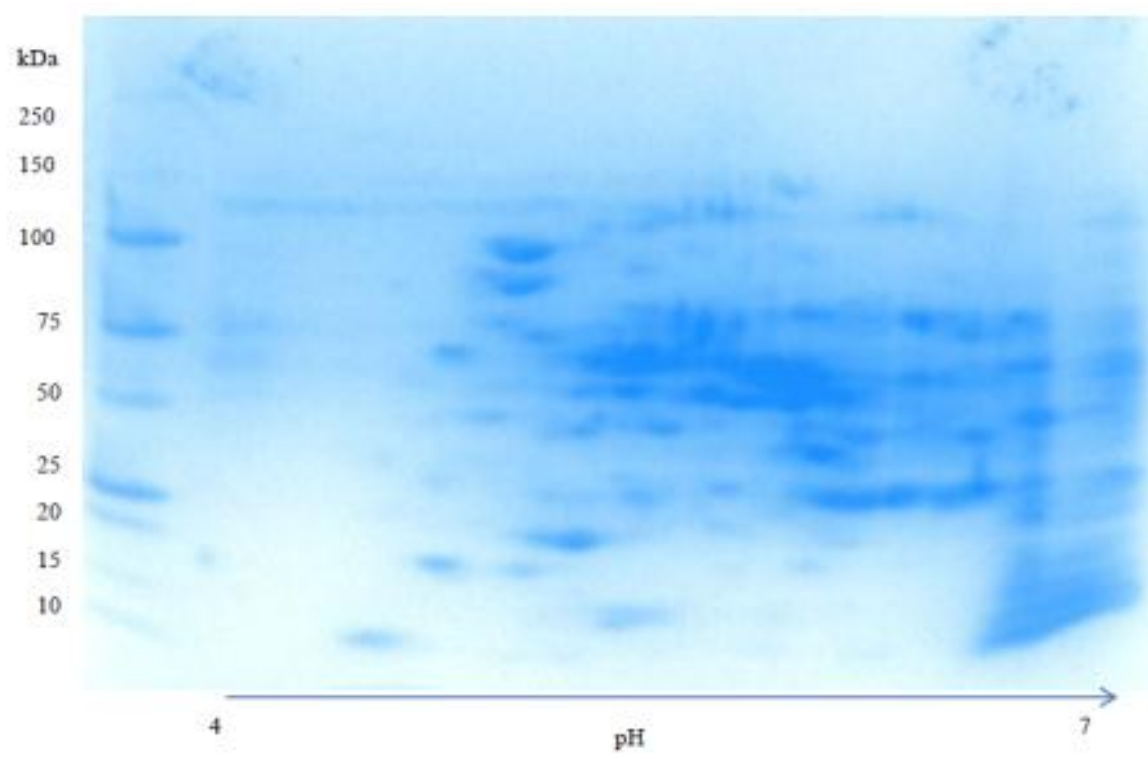

Figure 8. Expression of protein in E. coli $\mathrm{O} 157: \mathrm{H} 7$ at 4-7 $\mathrm{pH}$

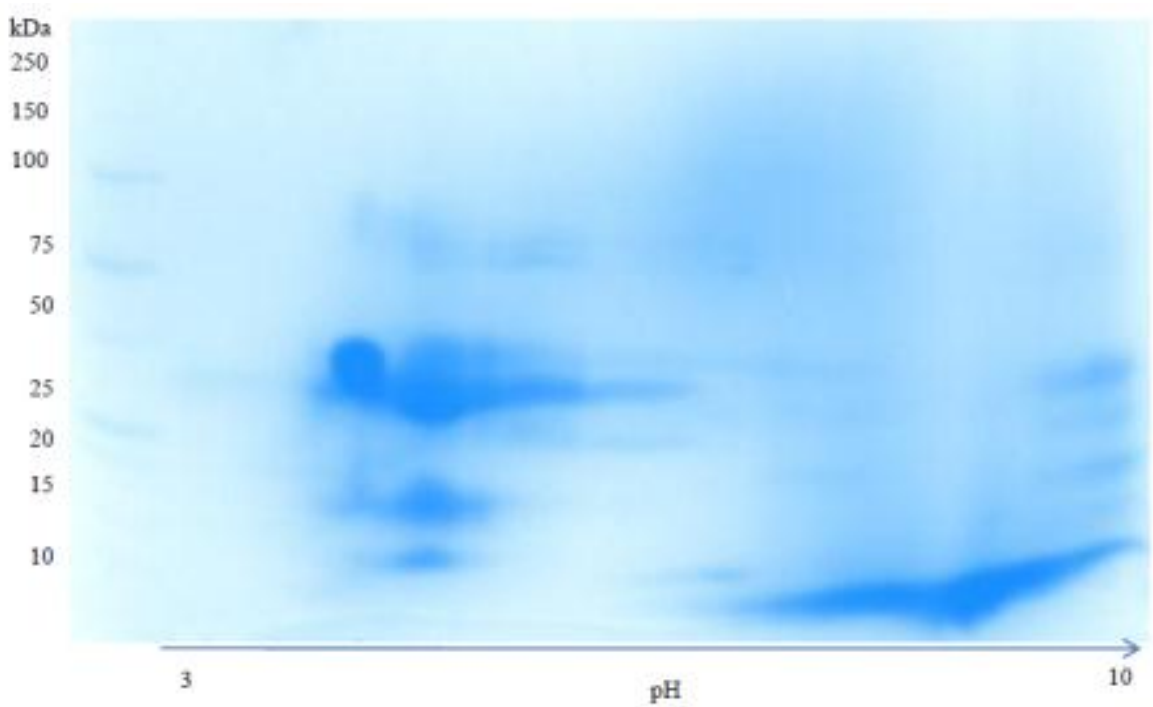

Figure 9. Number of protein spots expressed by in E. coli $\mathrm{O} 157: \mathrm{H} 7$ in milk at 3-10 pH 


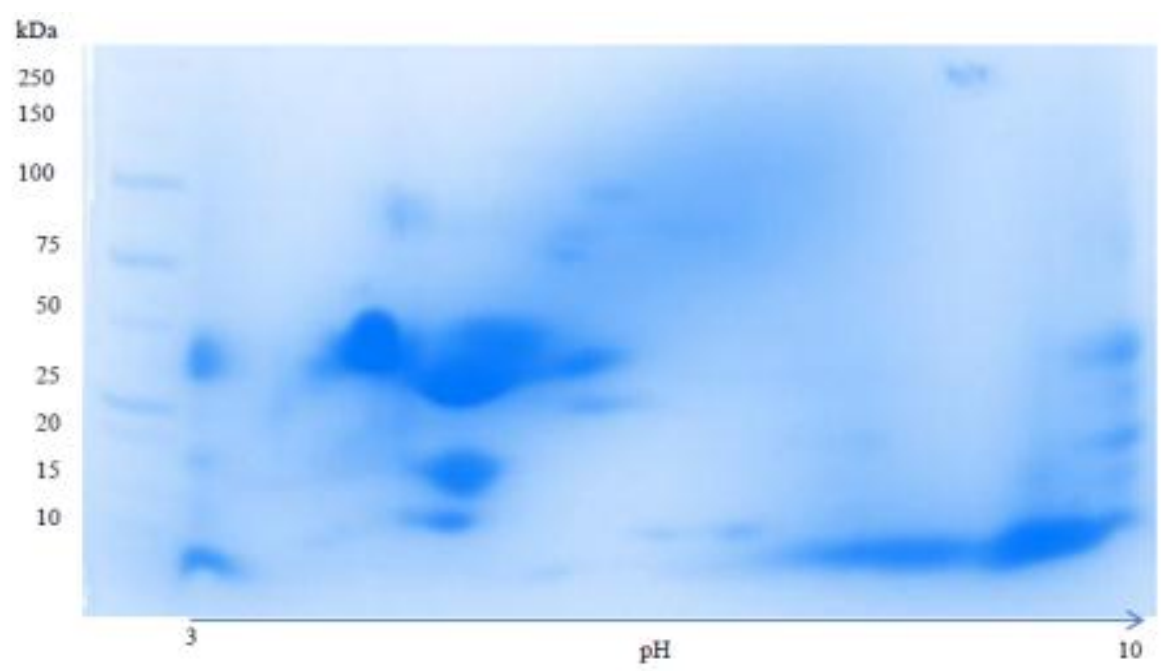

Figure 10. Effect of locust bean gum on number of protein expressed by E. coli $\mathrm{O} 157: \mathrm{H} 7$ in milk at 3-10 pH

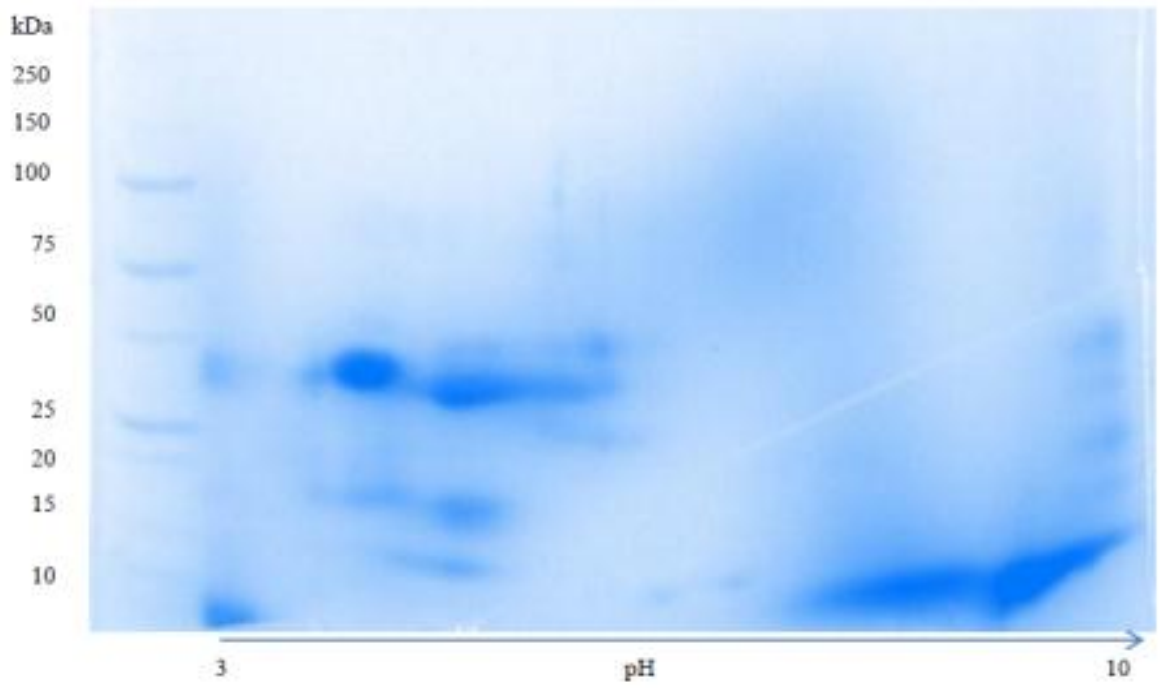

Figure 11. Effect of agar gum on number of protein expressed by E. coli $\mathrm{O} 157: \mathrm{H} 7 \mathrm{in}$ milk at 3-10 pH 


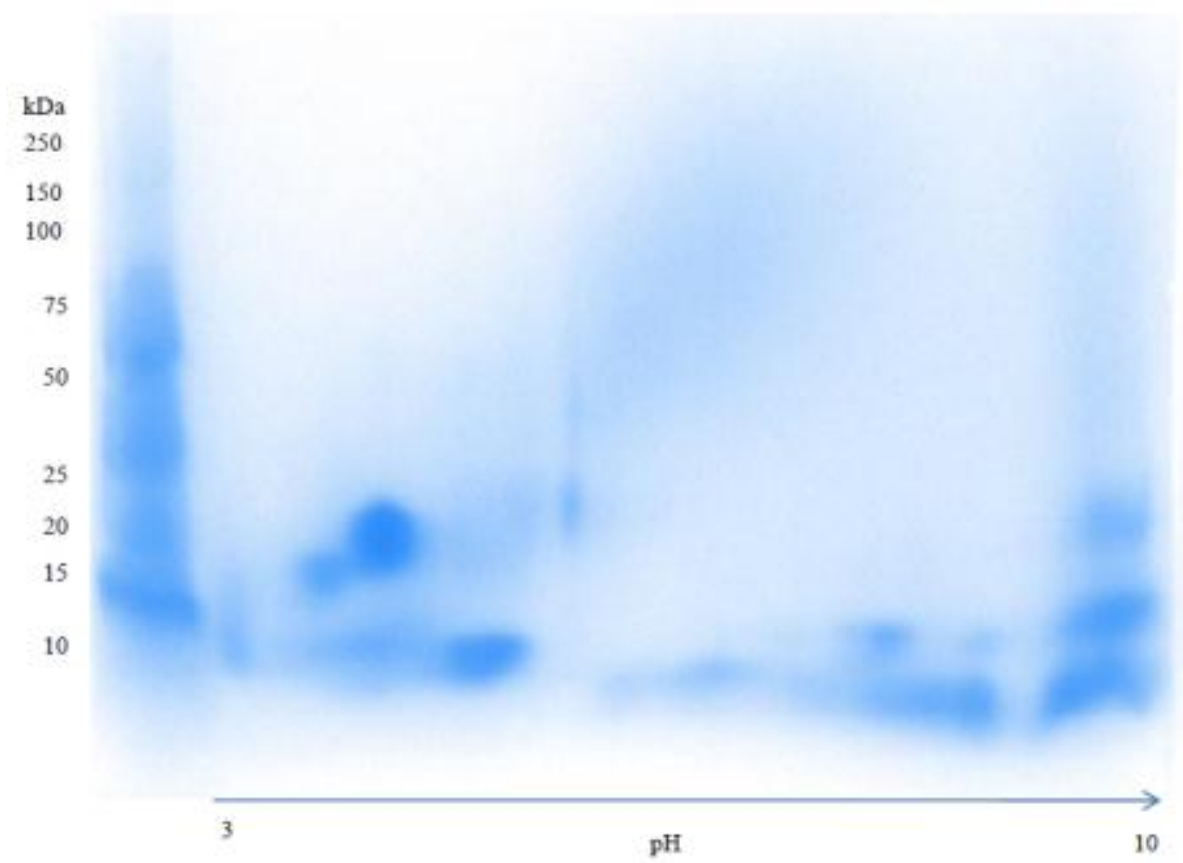

Figure 12. Effect of xanthan gum on number of protein expressed by E. coli $\mathrm{O} 157: \mathrm{H} 7$ in milk at 3-10 pH

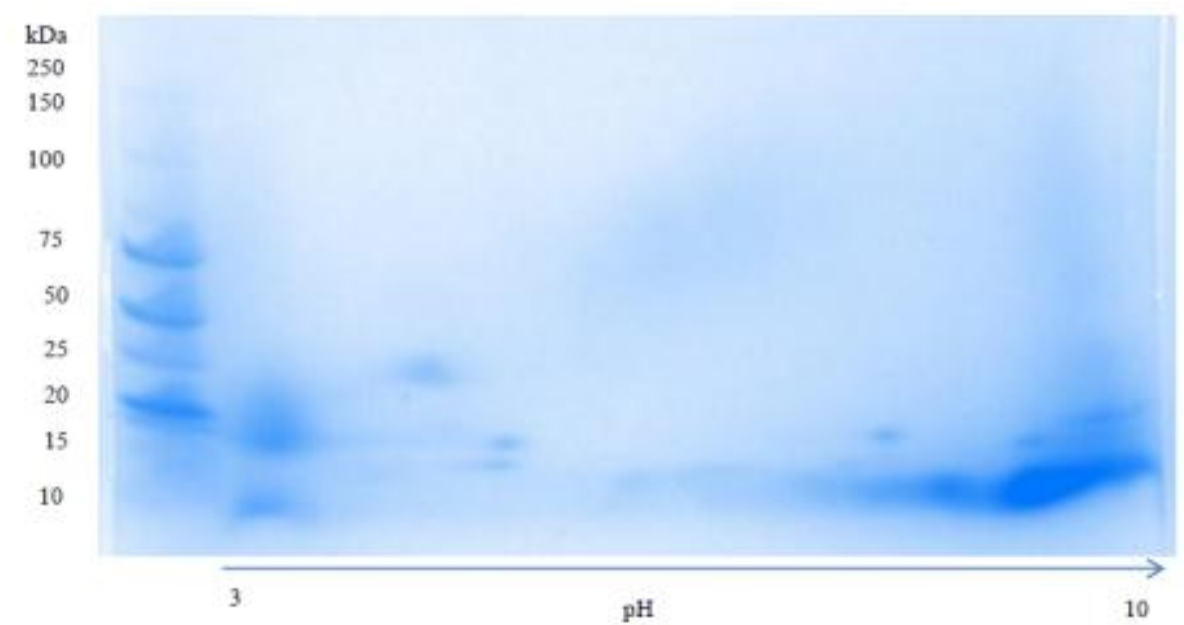

Figure 13. Effect of carrageenan-maltodextrin gum on number of protein expressed by E. coli O157: $\mathrm{H} 7$ in milk at $3-10 \mathrm{pH}$ 


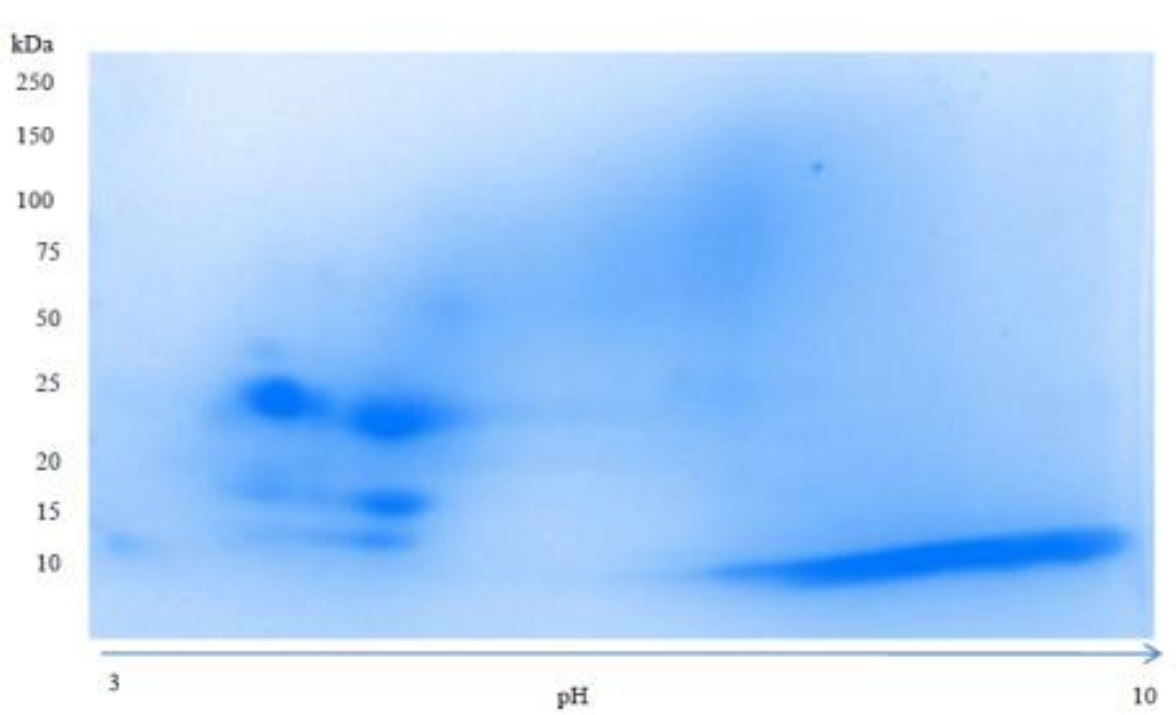

Figure 14. Effect of pectin gum on number of protein expressed by E. coli O157: $\mathrm{H} 7$ in milk at 3-10 pH

Control

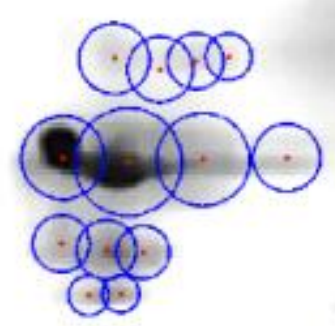

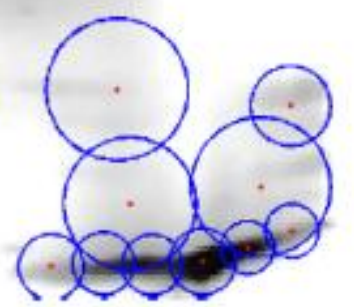

$\odot$

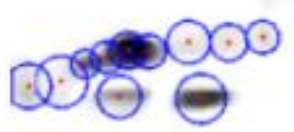

Carrageenan-maltodextrin $\odot$

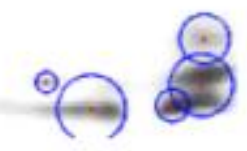

Locust bean

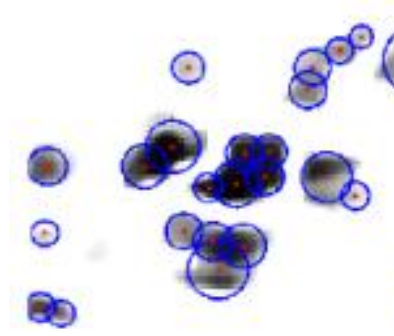

(1)

Agar
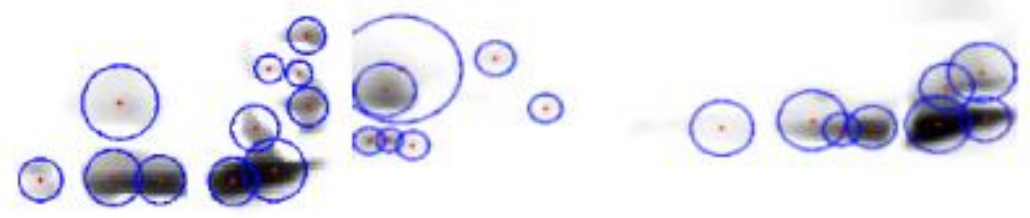

$\odot$

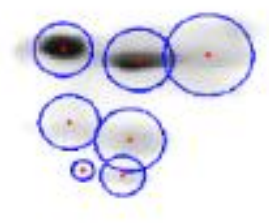

(i)

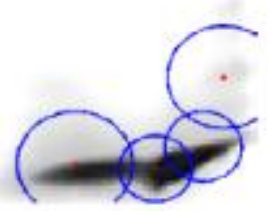

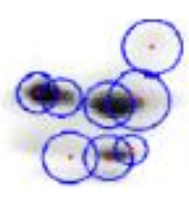
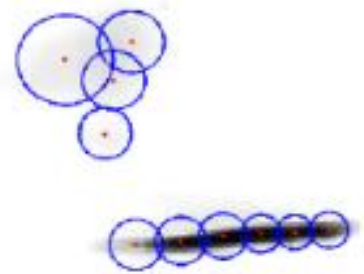

Figure 15. Protein peak spots detected in 2D image of $E$. coli $\mathrm{O} 157: \mathrm{H} 7$ in response to treatment with different gums 
Table 6. Effect of gums on number of protein spots at different $\mathrm{pH}$

\begin{tabular}{lll}
\hline Treatment & Number of peak spots & $\mathrm{pH}$ \\
\hline CT & 23 & $4-6,8-10$ \\
EC_101 & 35 & $3-5,8-10$ \\
EC_102 & 14 & $3-5,8-10$ \\
EC_103 & 17 & $3-5,8-10$ \\
EC_104 & 15 & $3-5,8-10$ \\
EC_105 & 18 & $3-5,8-10$ \\
\hline
\end{tabular}

Note: CT (Control); EC_101 (E. coli O157:H7 and locust bean); EC_102 (E. coli O157:H7and agar gum); EC_103 (E. coli O157:H7 and xanthan); EC_104 (E. coli O157:H7and carrageenan-maltodextrin); EC_105 (E. coli $\mathrm{O} 157: \mathrm{H} 7$ and pectin).

\section{Discussion}

This study investigated effects of polysaccharides gums on the growth of four different pathogenic bacteria and the microbial cellular response to different polysaccharide gums and antimicrobial agents' treatment at the proteome level.

\subsection{Growth Inhibitory Activity of Gums}

The two-log growth reduction of $S$. enterica grown in milk containing xanthan and pectin during refrigerated storage period could be due to poor interactions of $S$. enterica with xanthan and pectin in milk. A study conducted by Peter et al., (1989) revealed the accumulation of xanthan gum around cells grown on agar, whereas Contreras et al., (2005) have observed interactions during pathogenesis.

\subsection{Antimicrobial Activity of Gums}

Some select gums including agar (AG), carrageenan-maltodextrin (CM), locust bean (LB), pectin (PE), and xanthan (XA) were tested in combination with certain common antimicrobial agents including Tetracycline (TET) $30 \mu \mathrm{g}$; Doripenem (DOR) $10 \mu \mathrm{g}$; Imipenem (IMP) $10 \mu \mathrm{g}$; Cefixime (CFM) $5 \mu \mathrm{g}$; Cipropoxacin (CIP) $5 \mu \mathrm{g}$; Ceftazidime (CAZ) $30 \mu \mathrm{g}$; Kanamycin (KAN) $30 \mu \mathrm{g}$; and Meropenem (MEM) $10 \mu \mathrm{g}$ (Tables 2-5). Some of these common antimicrobial agents have been proven to be effective against certain pathogens in media whereas other showed resistance as observed in our previous study (Karlton-Senaye et al., 2016). In this current study, we investigated the effect of pathogens that have been pretreated with different gums in milk with further exposure to certain antimicrobial agents. The ability of the tested polysaccharide gums to increase the susceptibility of $S$. enterica to TET, DOR, CIP, CAZ, KAN and CFM (Fig. 2) and Escherichia coli O157:H7 to CFM whilst showing resistance in non-pretreated samples was expected (Fig 3). This is because plants including polysaccharides are capable of synthesizing secondary metabolites such as phenols, flavonoids and essential oils that have antimicrobial properties against pathogens. Carrageenan and pectin have been shown to be have antimicrobial activity against Listeria monocytogenes (Yamashita et al. 2003). Therefore, the ability of the gums to increase the susceptibility of the studied pathogens could be due to the presence of hydroxyl groups. Increase hydroxyl groups may lead to increased hydroxylation, which results in increased antimicrobial activity (Cowan et al., 2017). The number and site of hydroxyl group are found to be linked to their toxicity to microorganisms (Fullerton et al., 2011).

\subsection{Protein Expression}

Results from our study demonstrated changes in the total protein concentration and proteome profile of $E$. coli, $S$. aureus, L. monocytogenes and S. enterica in response to all the treatments tested. Previous studies have shown proteomic differences in L. monocytogenes (Huang et al., 2014), S. aureus (Liu et al., 2013;) and E. coli (Schimdt et al., 2016). In this study, we used 2-DE approach to investigate the relative protein expression dynamics in certain food borne pathogens in response to different polysaccharide gums and antimicrobial agents. Liu et al., 2013, showed proteomic changes in S. aureus in response to the antibiotic oxacillin. In the current study, the different foodborne pathogens tested showed antimicrobial susceptibility to the polysaccharide gum treatment and was possibly demonstrated at the molecular level observed in changes in total protein concentration and 2-D gel patterns.

In response to stress (growth conditions and antibiotics), bacteria undergo many changes at the physiological level. These changes include an increase in membrane fluidity and a decrease in translation level (Ingram, 1990). Various transcriptomic and proteomic studies have been done to demonstrate the physiological implication of 
cell wall stress in response to antibiotics and other treatments (Schimdt et al., 2016). This study reports the first comprehensive analysis of protein changes in foodborne pathogens specifically E. coli $\mathrm{O} 157: \mathrm{H} 7$ in response to different polysaccharide gums.

Microbes especially $E$. coli have been monitored to make changes at the molecular level in response to different stresses and growth conditions (Nystrom, 2004; Soufi et al., 2015). Previous studies have monitored these molecular adjustments at the protein level using 2-DE and quantitative mass spectrometry tools. For examples, system-wide protein changes have been studied in E. coli in response to ethanol stress (Soufi et al., 2015). Also, a study by Schmidt et al, 2016) identified protein allocation, expression regulation and post-translational adaptations in E. coli in response to 22 different experimental conditions. Similar proteome changes were observed in the current study; however, the specific proteins are yet to be identified and characterized.

Further studies are required to identify and characterize the biological function of these proteins using mass spectrometry. Furthermore, in E. coli $\mathrm{O} 157: \mathrm{H} 7$, small stress-induced proteins are missed using classical proteomic tools (Hemm et al., 2010). In addition to protein purification and mass spectrometry, identification and characterization of small proteins in response to gum treatment is warranted.

\section{Conclusion}

The results of this study showed that xanthan caused the most growth inhibition of Salmonella enterica, compared to the control. Inclusion of pectin in milk samples led to a 2-log reduction of Salmonella enterica during 21day refrigerated storage at $4{ }^{\circ} \mathrm{C}$. The addition of all tested gums in milk rendered Salmonella enterica susceptible to TET and DOR, whereas the control remained resistant. The highest inhibition zones were observed in E. coli $\mathrm{O} 157: \mathrm{H} 7$ exposed to carrageenan-maltodextrin-cefixime. Protein band of size 30kDa was the most prominent band among all treatments. The most protein spots with greater intensity were obtained in the samples treated with locust bean. Additionally, about four protein spots at the isoelectric point $\mathrm{pH} 3$ and molecular size ranging 10-50 $\mathrm{kDa}$ were distinctively present in locust bean treated groups but absent in the control. These findings indicated that tested gums were effective in inhibiting the growth of tested pathogens specifically Escherichia coli $\mathrm{O} 157: \mathrm{H7}$, thus they possess antimicrobial activity and have as antimicrobial agents. There was some correlation between the antimicrobial activity of the tested gums and the protein expression of the pathogens. Therefore, further studies are necessary to identify the specific proteins responsible for antimicrobial properties of gums. Our study confirms that gums possess some antimicrobial tendencies against select pathogenic microorganisms and impact gene expression. Thus, the antimicrobial properties of these gums make them possible candidate for food preservation. Gums could potentially be used in nutraceuticals to enhance recovery from pathogenic infections. Further studies are required to identify and characterize the biological function of these proteins and possible regulation at the level of transcription.

\section{Acknowledge}

This research was supported by State Appropriation Fund for North Carolina A\&T State University Center for Excellence in Post-Harvest Technologies at the North Carolina Research Campus, Kannapolis, NC. The authors would like to acknowledge the assistance of Dr. Marvin Aidoo for the 2DE image analysis using MATLAB.

\section{References}

Adjei-Fremah, S., Asiamah, E. K., Ekwemalor, K., Jackai, L., Schimmel, K., \& Worku, M. (2016). Modulation of bovine Wnt signaling pathway genes by cowpea phenolic extract. Journal of Agricultural Science, 8, 21. https://doi.org/10.5539/jas.v8n3p21

Adjei-Fremah, S., Jackai, L. E., \& Worku, M. (2015). Analysis of phenolic content and antioxidant properties of selected cowpea varieties tested in bovine peripheral blood. American Journal of Animal and Veterinary Sciences, 10, 235-245. https://doi.org/10.3844/ajavsp.2015.235.245

Ali, B. H., Ziada, A., \& Blunden, G. (2009). Biological effect of gum Arabic. A review of some recent studies. Food and Chemical Toxicology, 47, 1-8. https://doi.org/10.1016/j.fct.2008.07.001

Bonjar, S. (2004). Evaluation of antibacterial properties of some medicinal plants used in Iran. $J$ Ethnopharmacol, 94, 301-305. https://doi.org/10.1016/j.jep.2004.06.007

Brauner, J. M., Groemer, T. W., Stroebel, A., Grosse-Holz, S., Oberstein, T., Wiltfang, J., ... Maler, J. M. (2014). Spot quantification in two-dimensional gel electrophoresis image analysis: comparison of different approaches and presentation of a novel compound fitting algorithm. BMC bioinformatics, 15(1), 181. https://doi.org/10.1186/1471-2105-15-181

Contreras, N., Trujillo, G. O., Borges, F. \& Centeno. (2001). Análisis ultraestructural de la interacción de 
Xanthomonas axonopodis pv. phaseoli con genotipos resistentes, moderamente resistentes y suceptibles de Phaseolus vulgaris L. Interciencia, 26, 554-557. http://www.redalyc.org/pdf/339/33906205.pdf

Cowan, M. M. (1999). Plant products as antimicrobial agents. Clin Microbiol Rev, 12, 564-352. http://cmr.asm.org/

Demirci, F., Guven, K., Demirci, B., Dadandi, M. Y., \& Baser, K. H. C. (2008). Antibacterial activity of two Phlomis essential oils against food pathogens. Food Control, 19, 1159-1164. https://doi.org/10.1016/j.foodcont.2008.01.001

Friedman, M., Henika, P. R., Levin, C. E., \& Mandrell, R. E. (2006). Antimicrobial wine formulations against the food borne pathogens Escherichia coli O157:H7 and Salmonella enterica. Journal of Food Science, 71, 245-251. https://doi.org/10.1111/j.1750-3841.2006.00127.x

Fullerton, M., Khatiwada, J., Johnson, J., Davis, S., \& Williams., L. (2011). Determination of Antimicrobial Activity of Sorrel (Hibiscus sabdariffa) on Esherichia coli O157:H7 Isolated from Food, Veterinary, and Clinical Samples. Journal of Medicinal Food, 14, 950-956. https://doi.org/10.1089/jmf.2010.0200

Han, S. O., Yukawa, H., Inui, M., \& Doi, R. H. (2003). Regulation of Expression of Cellulosomal Cellulase and Hemicellulase Genes in Clostridium cellulovorans. Journal of Bacteriology, 185, 6067-6075. http://doi.org/10.1128/JB.185.20.6067-6075.2003

Hao, H., Cheng, G., Iqbal, Z., Ai, X., Hussain, H. I., Huang, L., ... Yuan, Z. (2014). Benefits and risks of antimicrobial use in food-producing animals. Frontiers in Microbiology, 5, 288. https://doi.org/10.3389/fmicb.2014.00288

Hemm, M. R., Paul, B. J., Miranda-Ríos, J., Zhang, A., Soltanzad, N., \& Storz, G. (2010). Small stress response proteins in Escherichia coli: proteins missed by classical proteomic studies. Journal of bacteriology, 192(1), 46-58. https://doi.org/10.1128/JB.00872-09

Huang, G., Mason, S. L., Hudson, J. A., Clerens, S., Plowman, J. E., \& Hussain, M. A. (2014). Proteomic differences between Listeria monocytogenes isolates from food and clinical environments. Pathogens, 3(4), 920-933. https://doi.org/10.3390/pathogens3040920

Ingram, L. O. (1990). Ethanol tolerance in bacteria. Critical reviews in biotechnology, 9, 305-319. https://doi.org/10.3109/07388558909036741

Islam, B., Khan, SN, Haque, I., Alam, M., Mushfiq, M., \& Khan, A. U. (2008). Novel anti-adherence activity of mulberry leaves: inhibition of Streptococcus mutans biofilm by 1-deoxynojirimycin isolated from Morus alba. J Antimicrob Chemother, 62, 751-757. https://doi.org/10.1093/jac/dkn253

Karlton-Senaye, B. D., Tahergorabi, Reza, Valerie, Giddings, \& Ibrahim, A. Salam. (2015). Effect of gums on the viability and $\beta$-galactosidase activity of Lactobacillus spp. in milk drink. International Journal of Food Science and Technology, 1, 32-40. https://doi.org/10.1111/ijfs.12633

Karlton-Senaye, B., Ayad, A., Davis, S., J Khatiwada, J., \& Williams., L. (2016). Interaction of gums and antimicrobialagents on susceptibility of selected foodborne pathogens. J Antimicro, 2, 2472-1212. http://dx.doi.org/10.4172/2472-1212.100012

Liu, X., Hu, Y., Pai, P. J., Chen, D., \& Lam, H. (2014). Label-free quantitative proteomics analysis of antibiotic response in Staphylococcus aureus to oxacillin. Journal of proteome research, 13(3), 1223-1233. https://doi.org/10.1021/pr400669d

Obanla, T., Adjei-Fremah, S., Gyawali, R., Zimmerman, T., Worku, M., \& Ibrahim, S. A. (2016). Effects of Long Term Exposure to Aspirin on Growth, Functionality and Protein Profile of Lactobacillus rhamnosus (LGG) (ATCC 53103). Journal of Food Research, 5(4), 46. https://doi.org/10.5539/jfr.v5n4p46

Pérez-Llarena, F. J., \& Bou, G. (2016). Proteomics as a Tool for Studying Bacterial Virulence and Antimicrobial Resistance. Frontiers in Microbiology, 7, 410. https://doi.org/10.3389/fmicb.2016.00410

Tajkarimi, M. M., Ibrahim, S. A., \& Cliver, D. O. (2010). Antimicrobial herb and spice compounds in food. Food Control, 21, 1199-1218. https://doi.org/10.1016/j.foodcont.2010.02.003

Worku, M., Abdalla, A., Adjei-Fremah, S., \& Ismail, H. (2016). The impact of diet on expression of genes involved in innate immunity in goat blood. Journal of Agricultural Science, $8,1$. https://doi.org/10.5539/jas.v8n3p1

Yamashita, S., Sugita-konishi, Y., \& Shimizu, M. (2001). In vitro bacteriostatic effects of dietary polysaccharides. 
Food Sci Technol Res, 7, 262-264. https://doi.org/10.3136/fstr.7.262

\section{Copyrights}

Copyright for this article is retained by the author(s), with first publication rights granted to the journal.

This is an open-access article distributed under the terms and conditions of the Creative Commons Attribution license (http://creativecommons.org/licenses/by/4.0/). 